\title{
TESTING FOR WAGE DISCRIMINATION IN U.S. MANUFACTURING
}

\author{
by
}

\section{Joyce Burnette * Wabash College}

CES 12-23 September, 2012

The research program of the Center for Economic Studies (CES) produces a wide range of economic analyses to improve the statistical programs of the U.S. Census Bureau. Many of these analyses take the form of CES research papers. The papers have not undergone the review accorded Census Bureau publications and no endorsement should be inferred. Any opinions and conclusions expressed herein are those of the author(s) and do not necessarily represent the views of the U.S. Census Bureau. All results have been reviewed to ensure that no confidential information is disclosed. Republication in whole or part must be cleared with the authors.

To obtain information about the series, see www.census.gov/ces or contact C.J. Krizan, Editor, Discussion Papers, U.S. Census Bureau, Center for Economic Studies 2K130F, 4600 Silver Hill Road, Washington, DC 20233, CES.Papers.List@census.gov. 


\begin{abstract}
In spite of the large literature on labor market discrimination, the quantity of solid evidence on discrimination is relatively limited. This is because evidence of discrimination is difficult to obtain. Two individuals may be treated equally, but this does not prove discrimination unless we can show that the differences in treatment were not justified by differences in productivity. The method most commonly used to identify wage discrimination, the Oaxaca decomposition, is flawed because any omitted variables that are correlated with gender will contribute to the unexplained portion of the wage gap, leading to an over- or under-estimation of wage discrimination. Audit studies provide more direct evidence of differential treatment, but are costly to carry out. Only a small number of studies attempt to measure worker productivity to see if wage differences are justified. This may be because the data needed to measure productivity are difficult to obtain. This paper tests for wage discrimination by gender and race by estimating relative productivity from 2002 Census of Manufacturing data linked to demographic information on workers from Longitudinal Employer-Household Dynamics (LEHD) files. Comparing the estimated productivity ratios to the observed wage ratios, I conclude that females and blacks face wage discrimination in US manufacturing.
\end{abstract}

*Any opinions and conclusions expressed herein are those of the author and do not necessarily represent the views of the U.S. Census Bureau. All results from 2002 data have been reviewed to ensure that no confidential information is disclosed. 
In spite of the large literature on labor market discrimination, the quantity of solid evidence on discrimination is relatively limited. This is because evidence of discrimination is difficult to obtain. Two individuals may be treated equally, but this does not prove discrimination unless we can show that the differences in treatment were not justified by differences in productivity. The method most commonly used to identify wage discrimination, the Oaxaca decomposition, is flawed because any omitted variables that are correlated with gender will contribute to the unexplained portion of the wage gap, leading to an over- or under-estimation of wage discrimination. Audit studies provide more direct evidence of differential treatment, but are costly to carry out. Only a small number of studies attempt to measure worker productivity to see if wage differences are justified. This may be because the data needed to measure productivity are difficult to obtain. This paper tests for wage discrimination by gender and race by estimating relative productivity from 2002 Census of Manufacturing data linked to demographic information on workers from Longitudinal Employer-Household Dynamics (LEHD) files. Comparing the estimated productivity ratios to the observed wage ratios, I conclude that females and blacks face wage discrimination in US manufacturing.

\section{Models of Discrimination}

This paper tests for employer discrimination as described by Becker (1971). This model assumes the employer has a taste for discrimination; the employer incurs disutility $d$ from hiring a minority worker. The employer compares the difference in market wages to his own $d$ to determine whether to hire the minority. Employers with a $d$ higher than the difference between minority and non-minority wages will find the cost of hiring the minority greater than the benefit and will not hire minority workers, while those with a $d$ lower than the wage difference will hire minority workers. The market wage of the minority worker is set to clear the market, i.e., so that enough employers are willing to hire minority workers. Unless there are enough nondiscriminating employers to hire all the minority workers, minority workers will earn less than non-minority workers. Wage discrimination is measured by the "Market Discrimination Coefficient," which is the difference between the wage ratio and the productivity ratio. ${ }^{1}$

Even if there is no wage discrimination, other forms of discrimination may exist. Barbara Bergmann's crowding model (Bergmann 1971, 1974) does not imply any difference between wages and productivity. In the crowding model, women are allowed to enter occupation B, but not occupation A. Women are then "crowded" into occupation B, where the supply of workers is large relative to the demand. Because the marginal product of labor is declining, the large supply of workers in occupation B leads to a low marginal product of labor and thus a low wage. In occupation A, where the supply of worker is small relative to the demand, marginal product and wage are both high. Within each occupation wages equal marginal product, but women have a low marginal product as a result of being crowded into the "female" occupation. This paper will compare productivity ratios to wage ratios; this method will identify wage discrimination, but cannot detect the presence of occupational crowding. Statistical discrimination in which group

${ }^{1}$ Becker defined the market discrimination coefficient as $\frac{\pi_{w}}{\pi_{n}}-\frac{\pi_{w}^{0}}{\pi_{n}^{0}}$, where $\pi_{i}$ is the market wage and $\pi_{i}^{0}$ represents “the equilibrium wage rates without discrimination.” Becker (1971), p. 17. 
averages are used to make hiring or wage decisions about individuals does not lead differences in average productivity and wage ratios if the employer uses the correct group averages. The test used in this paper cannot detect this form of discrimination.

\section{Literature Review}

Most studies of gender discrimination in the late-twentieth-century US agree that there is evidence of discrimination against women. Neumark, Bank, and Van Nort (1996) conduct an audit study of restaurants in Philadelphia and find that high-priced restaurants discriminate against women when hiring wait staff. This harms women, who are not able to access the highest-paying jobs. Based on the audition records of eight orchestras, Goldin and Rouse (2000) find that female musicians are more successful when auditions are blind (when evaluators can hear but not see the musician). Studies that estimate productivity ratios from production functions find that women's relative productivity is higher than their relative wage. Leonard (1984) finds that, in 1966, females were 75 percent as productive as men, but earned only 53 percent as much. Civil rights laws did not solve the problem; by 1977 women and men were equally productive, but women still earned only 54 percent as much as men. Hellerstein, Neumark, and Troske (1999) find a similar result for 1990: women were 84 percent as productive as men, but earned only 55 percent as much. Hellerstein, Neumark, and Troske (2002) find that plants that hire more women have higher operating income. This is consistent with discrimination because, if women earn less than their marginal product, then firms who hire more women should be more profitable. The relationship between the portion of the labor force that is female and profitability is positive for plants with high market power, and not significant for plants with low levels of market power.

While the evidence of gender discrimination is fairly consistent, there is conflicting evidence on racial discrimination. Neal and Johnson (1996) find that including AFQT test scores to the wage regression explains three-fourth of the racial gap for men and all of the gap for women. Using the same method and more recent data, Fryer (2011) finds that AFQT scores explain 40 percent of the wage gap for men, and all of the gap for women. Hellerstein, Neumark, and Troske (1999) find no evidence that blacks were underpaid, and Hellerstein, Neumark, and Troske (2002) find that hiring blacks has no significant effect on plant operating income, suggesting no discrimination. Other evidence is less optimistic. Audit studies conducted by the Urban Institute in Chicago and Washington suggest that African-American men are less likely to be hired than white men (Fix and Struyk, 1993). Resumes with names that sound AfricanAmerican are less likely to received a callback than identical resumes with white-sounding names (Bertrand and Mullainathan, 2004).

\section{Estimating Relative Productivity}

Many studies that claim to measure wage discrimination do not measure the marginal product of different workers, but use an Oaxaca decomposition to determine whether the wage gap can be explained by observable characteristics. ${ }^{2}$ To calculate the Oaxaca decomposition for the gender wage gap, a researcher would use individual-level data on wages to estimate separate wage

\footnotetext{
${ }^{2}$ See Goldin (1990) Ch. 4; Neumark (1988) p. 292.
} 
equations for men and women. The coefficients from these equations can then be used to decompose the gender difference in wages into an explained portion and an unexplained portion. ${ }^{3}$ The explained portion of the wage gap is the difference in observed characteristics, weighted by the coefficients of either the male or female wage equation. In other words, the explained wage gap is the difference between what men earn and what women would earn if their characteristics were rewarded according to the male wage regression, or the difference between what women earn and what men would earn if their characteristics were rewarded according to the female wage regression. The remainder, the unexplained portion, is interpreted as wage discrimination.

Using this method, Claudia Goldin concluded that wage discrimination by gender "emerged sometime between 1890 and 1940 in the white-collar sector of the economy." 4 According to her estimates, the unexplained portion of the wage gap rose from at most 20 percent of the difference in male and female earnings in manufacturing in 1890, to 55 percent in office work in 1940.”5 Numerous studies have used this method to measure wage discrimination over the past few decades, and a meta-analysis of these studies suggests that there has been a downward trend in wage discrimination since $1970 .^{6}$

Unfortunately, the Oaxaca decomposition is a poor measure of wage discrimination. The unexplained portion of the wage gap contains not only wage discrimination, but also the effects of any omitted variables. If there are any unobserved variables that are correlated with both wages and sex, then the unexplained portion of the wage gap will over- or under-estimate wage discrimination. For example, if women work fewer hours than men and hours are not included in as an independent variable, then part of the "unexplained" wage gap will be due to the difference in hours rather than discrimination. In general it is unlikely that a wage regression will include all of the individual characteristics relevant to productivity. The literature on the gender wage gap suggests that a wide range of factors affecting wages. Potential experience is a poor measure of actual experience for women, and women are more likely to quit their jobs for personal reasons. ${ }^{7}$ Choices such as college major affect earnings. ${ }^{8}$ Women may have less effort to expend for their jobs if they have heavy family responsibilities. ${ }^{9}$ Recent development have emphasized the importance of psychological differences between men and women; women are more risk averse and less overconfident than men, and they enjoy competition less. ${ }^{10}$ The literature on racial wage gaps has also found a variety of characteristics rarely included in wage equations that contribute to explaining the wage gap. While AFTQ scores explain a large portion of the racial wage gap, the NLSY is the only data set to include this measure. Psychological

${ }^{3} \ln \bar{w}_{m}-\ln \bar{w}_{f}=\left(\bar{X}_{m}-\bar{X}_{f}\right)^{\prime} \beta_{m}+\bar{X}_{f}^{\prime}\left(\beta_{m}-\beta_{f}\right)$

${ }^{4}$ Goldin (1990), p. 89.

5 ibid., p. 117.

6 Jarrell and Stanley (2004).

${ }^{7}$ Keith and McWilliams (1995).

${ }^{8}$ Daymont and Andreisani (1984).

${ }^{9}$ Becker (1985).

${ }^{10}$ Neiderle and Vesterlund (2007). See Bertrand (2011) for a wider review of the literature on psychological differences. 
characteristics such as self esteem have also been shown to have an impact on wages. ${ }^{11}$ Many of these factors are quite difficult to measure, and the chances that a wage regression will include all of them is nil.

Since the explanatory variables cannot include all individual characteristics that might be important for productivity, a large portion of the wage gap may remain unexplained simply because we do not have sufficient data to measure productivity, rather than because of discrimination. Often the unexplained portion of the wage gap is fairly large, suggesting a wide range of possible levels of wage discrimination, including no wage discrimination. ${ }^{12}$ This means that the unexplained portion of the wage gap will always contain the effects of omitted variables, and cannot be a reliable measure of wage discrimination. While researchers recognize that the unexplained portion of the wage gap includes the effects of omitted variables as well as wage discrimination, they often slip into calling it simply "wage discrimination."

Fortunately, there is a more accurate way to measure wage discrimination. Cross-sectional firm data can be used to estimate production functions, and to directly estimate the productivity of one group of workers relative another group. This more accurate measure of productivity ratio can be compared to the wage ratio to test for wage discrimination.

Assuming a Cobb-Douglas production function with homogenous labor, one could estimate the parameters of the production function by regressing the log of output on the logs of the inputs. If labor were homogenous, the production function would be

$$
\ln Q=A K^{a_{1}} L^{a_{2}}
$$

or

$$
\ln Q=\ln A+a_{1} \ln K+a_{2} \ln L
$$

where $\mathrm{Q}$ is the value of output, $\mathrm{K}$ is capital, and $\mathrm{L}$ is labor. If labor is not homogenous, however a different production function is needed, one that includes more than one labor input. One possible way to incorporate different kinds of labor into the production function is to treat each type of labor as a separate input in the Cobb-Douglas production function. This was the method used by Cox and Nye (1989) to estimate productivity in nineteenth-century French manufacturing. They estimated a production function of the form

$$
\ln Q=\ln A+\beta_{1} \ln M+\beta_{2} \ln F+\beta_{3} \ln K
$$

where $\mathrm{M}$ is the number of male workers and $\mathrm{F}$ is the number of female workers. ${ }^{13}$ This production function assumes that the elasticity of substitution between male and female labor is one. It also assumes that both male and female workers are necessary for production; if the firm hires zero units of either type of labor, then it cannot produce any output. Because this second assumption is obviously violated at many firms, this paper will use a different specification, one that allows male and female workers to be perfect substitutes for each other, though not

\footnotetext{
${ }^{11}$ Goldsmith, Veum, and Darity (1997).

12 Joyce Jacobsen (1994), p. 317, reports that, in 1990, 71 percent of the gender wage gap was unexplained for whites, and 70 percent for nonwhites.

${ }^{13}$ Cox and Nye (1989), p. 907.
} 
necessarily at a ratio of one-to-one. Leonard (1984) used a nested Cobb-Douglas production function, where the aggregate labor input was a linear combination of two types of workers. He assumed the production function was of the form

$$
\ln Q=e^{a_{1}} K^{a_{2}}\left(L_{A}+C L_{B}\right)^{a_{3}}
$$

In this production function the two types of labor are perfect substitutes. The ratio of the marginal products of the two types of labor is a constant, and does not depend on how many workers of each type are employed. While this nested Cobb-Douglas production function has many advantages, it cannot be estimated by a simple linear regression.

Various authors have used different techniques to estimate the nested model. Leonard used a Taylor-series approximation to make the non-linear equation (2) into the linear equation

$$
\ln Q=\alpha_{1}+\beta_{1} \ln K+\beta_{2} \ln L+\beta_{2}(C-1) P
$$

where $\mathrm{L}$ is the total number of workers employed, and $\mathrm{P}$ is the proportion of workers that are female. He notes, however, that the approximation is closer to the true relationship when $\mathrm{P}$ is small and $\mathrm{C}$ is close to one. Thus equation (3) is probably a bad approximation of the non-linear relationship when women are a large portion of the workforce. An alternative is to estimate equation (2) directly using non-linear regression or maximum likelihood. Hellerstein and Neumark (1995) estimate an expanded version of (2) with twelve kinds of labor categorized by age and occupation. Haegeland and Klette (1999) use maximum likelihood to estimate the parameters of a nested translog production function.

This paper will use non-linear regression to estimate a nested translog production function, in which aggregate labor input is a linear combination of the different types of labor. For the case where there are two types of labor, $\mathrm{A}$ and $\mathrm{B}$, the aggregate labor input is

$$
L^{*}=L_{A}+b_{1} L_{B}
$$

This function is easily generalized to allow multiple categories of workers. Including raw materials ( $\mathrm{RM})$ as an input, the production function is:

$$
\begin{aligned}
\ln Q= & a_{0}+a_{1} \ln K+a_{2} \ln R M+a_{3} \ln \left(L_{A}+b_{1} L_{B}\right)+a_{4} \ln K^{2}+a_{5} \ln R M^{2}+a_{6} \ln \left(L_{A}+b_{1} L_{B}\right)^{2} \\
& +a_{7} \ln K \ln R M+a_{8} \ln K \ln \left(L_{A}+b_{1} L_{B}\right)+a_{9} \ln R M \ln \left(L_{A}+b_{1} L_{B}\right)
\end{aligned}
$$

This specification assumes that the two types of labor are perfect substitutes, though not necessarily at a one-for-one ratio. This is reasonable if both types of workers can be used for the same tasks, but one type can produce more output per hour than the other. The specification makes it easy to test whether productivity ratio was equal to the wage ratio. The parameter $b_{1}$ measures the ratio of the marginal product of a type-B worker to the marginal product of a typeA worker: 


$$
\frac{d Q / d L_{B}}{d Q / d L_{A}}=b_{1} .
$$

Wage discrimination exists if the ratio wages is significantly smaller than $b_{1}$.

No attempt is made to control for hours of work, but both the productivity ratio and the wage ratio should be affected by such differences. Suppose type B workers worked half as many hours than type A workers but per hour are equally productivity. This would result in a productivity ratio of 0.5 . If they worked at the same wage, but worked half as many hours, the earnings ratio would also be 0.5 . The productivity ratio would equal the wage ratio, leading us to conclude there is no discrimination.

\section{Data}

Estimating equation (5) requires firm-level data on output, capital, and raw materials, as well as the labor force divided into demographic groups. The Census of Manufactures includes most of this data, but does not report the gender or racial composition of the workforce. Fortunately information on individual workers from the Individual Characteristics Files (ICF) and Employment History Files (EHF) can be linked to the Census of Manufactures via employer identification numbers. I first merged ICF and EHF data using the individual identifier (PIK), keeping only individuals who worked in the third quarter. I created dummy variables indicating sex, race, and age in three categories (under 35, 35-54, and 55+). I then summed the total number of workers at each firm (by SEIN), creating observations indicating the total number of male and female workers linked to each firm, and their total earnings in quarter 3 . I did this for each state where data was available (22 states), and merged these states together, aggregating the data to the firm level (by EIN). I also aggregated 2002 Census of Manufacturing data to the firm level, and linked it to the worker data using the firm identification number (EIN). The result was a data set containing information on firm inputs and output, as well as demographic information on the workforce and quarterly earnings by demographic category.

The data set is similar to that constructed by Hellerstein, Neumark, and Troske (1999), except that, since I have firm identification numbers, I did not have to confine myself to firms that were unique in their industry/location cell. I was also more successful in matching workers to firms. While Hellerstein, Neumark, and Troske matched on average 12 percent of a plant's workforce, my matching was much more thorough. I matched more workers to a firm than total employment in the Census of Manufactures. This may be due to turnover, since the Census of Manufactures measures employment as a point in time rather than every person ever employed during a quarter. Because the total number of workers matched does not equal employment reported in the Census of Manufactures, I use the Census of Manufactures data for the total number of workers, and rely on the matched demographic data to estimate the percentage of workers in each category.

\section{Gender Discrimination}

I begin by examining the relative productivity of female workers. I estimate the function 


$$
\begin{aligned}
\ln Q= & a_{0}+a_{1} \ln K+a_{2} \ln R M+a_{3} \ln \left(M+b_{1} F\right)+a_{4} \ln K^{2}+a_{5} \ln R M^{2}+a_{6} \ln \left(M+b_{1} F\right)^{2} \\
& +a_{7} \ln K \ln R M+a_{8} \ln K \ln \left(M+b_{1} F\right)+a_{9} \ln R M \ln \left(M+b_{1} F\right)
\end{aligned}
$$

using non-linear least squares. Table 1 reports the estimated productivity ratios $\left(\mathrm{b}_{1}\right.$ from equation 6) and the ratio of average quarterly earnings by gender. There is evidence of wage discrimination because the productivity ratio is significantly higher than the wage ratio. However, the extent of the discrimination is smaller than that reported by Hellerstein, Neumark, and Troske (1999) for 1990. They estimated a female-male productivity ratio of 0.84 , which is not significantly different from first row in Table 1 . However, they found a much lower wage ratio (0.55). My results suggest that between 1990 and 2002 the extent of gender wage discrimination fell as relative female wages rose. In 1990 the gap between the productivity and wage ratios was 0.29 , and in 2002 this gap was only 0.12 . Then entire decline in the gap was due to rising relative female wages.

There is variation across industries in the both productivity ratios and wage ratios. Figure 1 graphs wage ratios against productivity ratios for 21 three-digit industries. The 45-degree line shows the null hypothesis of no discrimination, which would imply productivity ratios that equal the wage ratios. Most of the industries fall below the 45-degree line, which is the range of wage discrimination against women. Of the 21 industries, 14, or two-thirds, have evidence of wage discrimination against women.

Across industries there is a positive correlation (0.21) between the productivity ratio and the share of the workforce that is hired for nonproduction tasks. This suggests that relative female productivity is higher in non-production tasks than in production tasks, which is consistent with women having a comparative advantage in "brain" rather than "brawn" tasks. ${ }^{14}$ The wage ratio, however, is negatively correlated with the percentage of the workforce in nonproduction tasks. This suggests that wage discrimination is highest in nonproduction work. Consistent with this theory, there is a positive correlation between the percentage of an industry's workforce in nonproduction tasks and the gap between the productivity and wage ratios. Goldin (1990) suggested that wage discrimination first appeared among clerical workers; it still may be more prevalent among white-collar workers.

\section{Gender Discrimination by Age}

To examine how the gender gap changes over the life cycle, I divide the workforce into three age groups. Young workers are less than 35 years old, middle-aged workers are 35 to 54, and old workers are 55 and older. The function estimated is a nested translog production function similar to equation (6), but with aggregate labor

$$
L^{*}=M_{Y}+b_{1} M_{M}+b_{2} M_{O}+b_{3} F_{Y}+b_{4} F_{M}+b_{5} F_{O},
$$

\footnotetext{
${ }^{14}$ See Goldin (2006) for a discussion of brain vs. brawn tasks.
} 
where the subscripts Y, M, and O indicate young, middle-aged, and old workers. ${ }^{15}$ Table 2 shows the results. As workers age the female-male productivity ratio increases slightly, but the wage ratio falls substantially. While there is no evidence of wage discrimination for young workers, there is wage discrimination among middle-aged and older workers. The gap between the productivity ratio and the wage ratio is greatest for the oldest workers. This pattern could be due to cohort effects, or to wage profiles that increase more for men than for women.

Economists have hypothesized that employers encourage loyalty and discourage shirking by using delayed compensation. ${ }^{16}$ In such a compensation scheme, workers are paid less than their current marginal product when young, and more than their current marginal product when old. This gives workers a reason to remain at their current job, because future earnings are higher in the current job than in an alternative job. Kotlikoff and Gokhale (1992) find evidence of delayed compensation for workers at one firm. My results also suggest delayed compensation for both genders. Productivity increases slightly as workers move into middle age, but wages increase substantially, 62 percent for men and 35 percent for women. For workers aged 55 and older, men earn 88 percent more than young men, even though they are not significantly more productive. Older women earn 39 percent more than young women, and are only 11 percent more productive. Thus both genders see their wages increase more than their productivity, but men seem to benefit more than women from delayed compensation. This is consistent with a literature suggesting that internal labor markets treat men and women differently and provide men with more opportunities for wage growth. ${ }^{17}$

\section{Racial Discrimination}

I also divide the labor force into four race categories, white, black, Asian, and other. Since whites are the most numerous category, they are chosen as the numeraire, and other groups are measured relative to whites. I estimate a nested production function with aggregate labor equal to

$$
L^{*}=W+b_{1} B+b_{2} A+b_{3} O
$$

where $\mathrm{W}$ is the number of whites hired, $\mathrm{B}$ is the number of blacks, $\mathrm{A}$ is the number of Asians, and $\mathrm{O}$ is the number of workers of other races. Table 3 gives the estimated productivity ratio and the ratios of average wages. The black/white productivity ratios is higher when state and industry controls are included. With controls, a black worker is nearly as productive as a white worker. Blacks, however, earn significantly less than whites, so there is a significant gap between wages and productivity that is not consistent profit maximization. Asians earn more than whites, but are less productive, suggesting that they were overpaid. Workers of other races are slightly over-paid, but the gap between the productivity ratio and the wage ratio is relatively small.

These results are quite different from those of Hellerstein, Neumark, and Troske (1999), who estimated found no evidence of wage discrimination against blacks. Their point estimate of

\footnotetext{
${ }^{15}$ I run different estimations, varying the omitted category, to get a simple SE for the productivity ratio I want.

16 See, for example, Lazear, 1979.

${ }^{17}$ See Owen (2001) and Seltzer (2011).
} 
relative productivity suggests that blacks are 18 percent more productive than whites, but the black/white productivity ratio is not significantly different from one. They also estimate that blacks earn 12 percent more than whites. My estimates of relative productivity are consistent with theirs, since neither estimate is significantly different from one. The difference in conclusion results from difference in wage ratios. While Hellerstein, Neumark, and Troske estimate that blacks earn 112 percent as much as whites, I find blacks earning only 69 percent as much. Given other research on relative black wages, I find my estimate of the wage ratio more plausible. Altonji and Blank (1999) find that the black-white ratio of hourly earnings is 0.72 for males and 0.86 for females. Blacks may be positively selected into manufacturing, selection would have to be extreme to cause blacks to earn 12 percent more than whites.

Fryer (2011) finds a growing achievement gap between black and white children between ages 4 and high school. While he finds that AFQT scores explain much of the racial wage gap, for men he does find a wage gap of 11 percent that is not explained by AFQT scores. This leaves some room for discrimination, though it suggests that the extent of discrimination is smaller than that estimated here.

\section{An Alternative Methodology: Profitability}

In his original formulation of the employer discrimination model, Becker (1971) suggested that employers who engage in wage discrimination will earn lower profits. Discriminating employers fail to hire minority workers whose wages are lower than their marginal product, and thus give up potential profits. This led Becker to suggest that wage discrimination should be more prevalent in industries where firms have more market power, and less prevalent in competitive industries. It also lead Hellerstein, Neumark, and Troske (2002) to an alternative test for discrimination. If there is discrimination against a group, then firms hiring more workers from that group should be more profitable. Hellerstein, Neumark, and Troske (2002) find that hiring more females is associated with higher profits, while hiring more blacks does not affect profits. This suggests wage discrimination against females but not blacks.

I test for the effects of labor force composition on profitability using two different measures of profitability. The first is value added less payroll costs, divided by total output (the value of shipments plus the growth in inventories). The second is the total output less the costs of materials and payroll, divided by total output. To control for capitalization I include capital as a percent of sales. To control for market power I include “firm share”, which measures firm's sales as a percentage of all the firms in the sample in the same three-digit industry. Table 4 shows the results of these regressions. The only demographic group to have an effect on profitability is the percentage black. While the percentage of blacks hired has no effect on profits under the first definition, it has a significant positive effect on profits under the second definition. Neither females nor older workers have any significant effect on profits. Unlike the estimates in Table 2, this specification requires the effect of gender to be the same for younger and older workers. To see if this mattered, I ran an alternative specification including the percentage of young women, middle-aged women, and old women as separate categories. ${ }^{18}$

\footnotetext{
18 The specification divided the workforce into six categories and included variables for the percentage of the workforce that were middle-aged men and older men, as well as young women, middle-aged women, and older women. Young men were the omitted category.
} 
However, none of the three categories had any significant effect on profits. Thus this alternative measure of discrimination finds some (non-robust) evidence of discrimination against blacks, but no evidence of discrimination against females or in favor of older workers.

\section{Conclusion}

While the evidence in this paper is consistent with other studies of gender discrimination in that it finds gender discrimination is present in the US labor market, I find that the gap between the wage ratio and the productivity ratio is much smaller than previous estimates, suggesting convergence towards equality. While the productivity ratio did not change between 1990 and 2002, remaining at approximately 85 percent, the wage ratio increased from 0.55 to 0.72 . While I find that females are 85 percent as productive as males, this difference may be the result of the quantity of labor input as well as the quality of that input. If female employees worked, on average, fewer hours in a quarter than male employees, this would cause female productivity to be less than male productivity.

In contrast to more optimistic evidence on racial discrimination, I also find evidence of wage discrimination against blacks. Hellerstein, Neumark, and Troske (1999) find no evidence of discrimination against blacks, but they estimate that blacks were paid more than whites. Neal and Johnson (1996) and Fryer (2011) both conclude that differences in test scores explain a large portion, but not all, of the racial gap in male wages, and thus are consistent with the existence of some discrimination. My result lead to the conclusion that wage discrimination against blacks is more important than other studies have suggested. 


\section{Bibliography}

Altonji, Joseph, and Blank, Rebecca, 1999, "Race and Gender in the Labor Market,” in O. Ashenfelter and D. Card., eds., Handbook of Labor Economics, Amsterdam: Elsevier.

Becker, Gary, 1985, “Human Capital, Effort, and the Sexual Division of Labor,” Journal of Labor Economics, 3: S33-S58

Becker, Gary, 1971, The Economics of Discrimination, $2^{\text {nd }}$ ed., Univ. of Chicago Press.

Bergmann, Barbara, 1971, “The Effect on White Incomes of Discrimination in Employment,” Journal of Political Economy, 79:294-313.

Bergmann, Barbara,, 1974, “Occupational Segregation, Wages and Profits when Employers Discriminate by Race or Sex,” Eastern Economic Journal, 1:103-110

Bertrand, Marianne, 2001, “New Perspectives on Gender,” in O. Ashenfelter and D. Card, eds., Handbook of Labor Economics, Amsterdam: Elsevier.

Bertrand, Marianne, and Mullainathan, Sendhil, 2004, "Are Emily and Greg More Employable than Lakisha and Jamal? A Field Experiment on Labor Market Discrimination,” American Economic Review, 94:991-1013

Cox, Donald, and Nye, John Vincent, 1989, "Male-Female Wage Discrimination in Nineteenth-Century France,” Journal of Economic History, 49:903-920

Daymont, Thomas, and Andrisani, Paul, 1984, "Job Preferences, College Major, and the Gender Gap in Earnings," Journal of Human Resources, 19:408-428.

Fix, Michael, and Struyk, Raymond, eds., 1993, Clear and Convincing Evidence: Measurement of Discrimination in America, Urban Institute Press, Washington.

Fryer, Roland, 2011, "Racial Inequality in the $21^{\text {st }}$ Century: The Declining Significance of Discrimination,” in O. Ashenfelter and D. Card,, eds., Handbook of Labor Economics, Amsterdam: Elsevier.

Goldin, Claudia, 1990, Understanding the Gender Gap: An Economic History of American Women, New York: Oxford University Press.

Goldin, Claudia, 2006, “The Rising (and then Declining) Significance of Gender,” in F. Blau, M. Brinton, and D. Brusky, eds., The Declining Significance of Gender? New York: Russell Sage Foundation, pp. 67101.

Goldin, Claudia, and Rouse, Cecilia, 2000, “Orchestrating Impartiality: The Impact of 'Blind' Auditions on Female Musicians,” American Economic Review, 2000, XL:715-742

Goldsmith, Arthur, Veum, Jonathan, and Darity, William, 1997, “The Impact of Psychological and Human Capital on Wages,” Economic Inquiry, 35:815-829. 
Haegeland, Torbjorn, and Klette, Tor Jakob, 1999, "Do Higher Wages Reflect Higher Productivity? Education, Gender and Experience Premiums in a Matched Plant-Worker Data Set” in Haltwanger, Lane, Spletzer, Theeuwes, and Troske, eds., The Creation and Analysis of Employer-Employee Matched Data, Amsterdam: Elsevier, pp. 231-259.

Hellerstein, Judith, and Neumark, David, 1995, “Are Earnings Profiles Steeper Than Productivity Profiles? Evidence from Israeli Firm-Level Data,” Journal of Human Resources, 30:89-112.

Hellerstein, Judith, Neumark, David, and Troske, Kenneth, 1999, "Wages, Productivity, and Worker Characteristics: Evidence from Plant-Level Production Functions and Wage Equations,” Journal of Labor Economics, 17:409-446.

Hellerstein, Judith, Neumark, David, and Troske, Kenneth, 2002, “Market Forces and Sex Discrimination,” Journal of Human Resources, 2002, 37:353-380

Jacobsen, Joyce, 1994, The Economics of Gender, Oxford: Blackwell

Jarrell, Stephe, and Stanley, T.D., 2004, "Declining Bias and Gender Wage Discrimination? A MetaRegression Analysis," Journal of Human Resources, 39:828-838

Keith, Kristen, and McWilliams, Abagail, 1995, “The Wage Effects of Cumulative Job Mobility,” Industrial and Labor Relations Review, 49:121-137.

Kotlikoff, Laurence, and Gokhale, Jagadeesh, 1992, “Estimating a Firm’s Age-Productivity Profile Using the Present Value of Workers’ Earnings,” Quarterly Journal of Economics, 107: 1215-1242

Lazear, Edward, 1979, “Why is there Mandatory Retirement?” Journal of Political Economy, 87:126164.

Leonard, Jonathan, 1984, “Antidiscrimination or Reverse Discrimination: The Impact of Changing Demographics, Title VII, and Affirmative Action on Productivity,” Journal of Human Resources, 19:145174

Neal, Derek, and Johnson, William, 1996, “The Role of Premarket Factors in Black-White Wage Differences,” Journal of Political Economy, 104:869-895

Neumark, David, 1988, “Employers’ Discriminatory Behavior and the Estimation of Wage Discrimination,” Journal of Human Resources, 23:279-295

Neumark, David, Bank, Roy, and Van Nort, Kyle, 1996, "Sex Discrimination in Restaurant Hiring: An Audit Study,” Quarterly Journal of Economics, 111:915-941

Niederle, Muriel, and Vesterlund, Lise, 2007, "Do Women Shy Away from Competition? Do Men Compete Too Much?” Quarterly Journal of Economics, 122:1067-1102.

Owen, Laura, 2001, "Gender Differences in Labour Turnover and the Development of Internal Labor Markets in the United States during the 1920s,” Enterprise \& Society, 2:41-71.

Seltzer, Andrew, 2011, “Female Salaries and Careers in British Banking, 1915-41,” Explorations in Economic History, 48: 461-477. 
Table 1

Female-Male Productivity and Wage Ratios

\begin{tabular}{|c|c|c|c|}
\hline & $\begin{array}{l}\text { Productivity } \\
\text { Ratio } \\
\end{array}$ & $\begin{array}{l}\text { Wage } \\
\text { Ratio } \\
\end{array}$ & Gap \\
\hline No State/Industry Controls & $\begin{array}{r}0.835 \\
(0.006)\end{array}$ & 0.717 & $0.118^{*}$ \\
\hline With State/Industry Controls & $\begin{array}{r}0.865 \\
(0.007)\end{array}$ & 0.717 & $0.148 *$ \\
\hline
\end{tabular}

* = significantly different form zero at the $5 \%$ level $\mathrm{N}>100,000$.

Table 2

Productivity and Wage Ratios by Age and Gender

\begin{tabular}{|l|r|r|r|}
\hline & Productivity & Wage & Gap \\
\hline Female-Male Ratio by Age & & & \\
\hline Young $\left(\mathrm{F}_{\mathrm{Y}} / \mathrm{M}_{\mathrm{Y}}\right)$ & $\begin{array}{r}0.844 \\
(0.013)\end{array}$ & 0.835 & 0.009 \\
\hline Middle-Age $\left(\mathrm{F}_{\mathrm{M}} / \mathrm{M}_{\mathrm{M}}\right)$ & 0.851 & 0.694 & $0.157^{*}$ \\
& $(0.010)$ & & \\
\hline Old $\left(\mathrm{F}_{\mathrm{O}} / \mathrm{M}_{\mathrm{O}}\right)$ & 0.928 & 0.618 & $0.310^{*}$ \\
& $(0.018)$ & & \\
\hline Male Age Profile & & & \\
\hline $\mathrm{M}_{\mathrm{M}} / \mathrm{M}_{\mathrm{Y}}$ & 1.053 & 1.621 & $-0.568^{*}$ \\
\hline $\mathrm{M}_{\mathrm{O}} / \mathrm{M}_{\mathrm{Y}}$ & $(0.011)$ & & \\
\hline & 1.005 & 1.877 & $-0.872^{*}$ \\
\hline Female Age Profile & $(0.014)$ & & \\
\hline $\mathrm{F}_{\mathrm{M}} / \mathrm{F}_{\mathrm{Y}}$ & & & \\
\hline $\mathrm{F}_{\mathrm{O}} / \mathrm{F}_{\mathrm{Y}}$ & 1.062 & 1.346 & $-0.284^{*}$ \\
\hline
\end{tabular}

* = significantly different form zero at the $5 \%$ level

All estimations include state and industry controls. 
Table 3

Productivity and Wage Ratios by Race

\begin{tabular}{|c|c|c|c|c|}
\hline & & $\begin{array}{l}\text { Productivity } \\
\text { Ratio }\end{array}$ & $\begin{array}{l}\text { Wage } \\
\text { Ratio }\end{array}$ & Gap \\
\hline \multirow[t]{3}{*}{$\begin{array}{l}\text { No State/Industry } \\
\text { Controls }\end{array}$} & Black/White & $\begin{array}{r}0.854 \\
(0.017)\end{array}$ & 0.693 & $0.161^{*}$ \\
\hline & Asian/White & $\begin{array}{r}0.888 \\
(0.010)\end{array}$ & 1.157 & $-0.269 *$ \\
\hline & Other/White & $\begin{array}{r}0.862 \\
(0.007)\end{array}$ & 0.894 & $-0.032 *$ \\
\hline \multirow[t]{3}{*}{$\begin{array}{l}\text { With State/Industry } \\
\text { Controls }\end{array}$} & Black/White & $\begin{array}{r}0.970 \\
(0.018) \\
\end{array}$ & 0.693 & $0.277 *$ \\
\hline & Asian/White & $\begin{array}{r}0.879 \\
(0.011) \\
\end{array}$ & 1.157 & $-0.278 *$ \\
\hline & Other/White & $\begin{array}{r}0.869 \\
(0.008)\end{array}$ & 0.894 & $-0.025 *$ \\
\hline
\end{tabular}

\section{Table 4}

The Effect of Workforce Composition on Profitability

\begin{tabular}{|l|r|r|r|r|}
\hline & \multicolumn{2}{|c|}{ Profit 1} & \multicolumn{2}{c|}{ Profit 2 } \\
\hline Constant & 0.3208 & 0.2615 & 0.3107 & 0.1589 \\
& $(0.0425)$ & $(0.1254)$ & $(0.0512)$ & $(0.1509)$ \\
\hline Percent Female & -0.0446 & -0.0374 & -0.0187 & 0.0258 \\
& $(0.0567)$ & $(0.0647)$ & $(0.0682)$ & $(0.0779)$ \\
\hline Percent Young & 0.0055 & 0.0140 & -0.0097 & -0.0189 \\
& $(0.0689)$ & $(0.0701)$ & $(0.0829)$ & $(0.0843)$ \\
\hline Percent Old & 0.0469 & 0.0387 & 0.1187 & 0.1148 \\
& $(0.0954)$ & $(0.0961)$ & $(0.1149)$ & $(0.1157)$ \\
\hline Percent Black & 0.0123 & 0.0079 & 0.4038 & 0.3875 \\
& $(0.1168)$ & $(0.1249)$ & $(0.1406)$ & $(0.1504)$ \\
\hline Percent Other Race & -0.1210 & -0.0972 & -0.1123 & -0.0683 \\
& $(0.0466)$ & $(0.0591)$ & $(0.0561)$ & $(0.0711)$ \\
\hline Capital/Sales & -0.0384 & -0.0427 & -0.0412 & -0.0438 \\
& $(0.0206)$ & $(0.0208)$ & $(0.0248)$ & $(0.0250)$ \\
\hline Firm Share & 1.2611 & 1.4741 & 0.8032 & 0.9950 \\
& $(2.4663)$ & $(3.1655)$ & $(2.9684)$ & $(3.8101)$ \\
\hline Industry and State & No & Yes & No & Yes \\
Controls & & & & \\
\hline
\end{tabular}

Profit $1=$ (Value Added - Payroll)/(Total Value of Shipments + Growth in Inventories)

Profit $2=$ (Total Value of Shipments + Growth in Inventories - Payroll - Cost of Materials)/ (Total Value of Shipments + Growth in Inventories) 
Figure 1

Productivity and Wage Ratios in 21 Three-Digit Industries

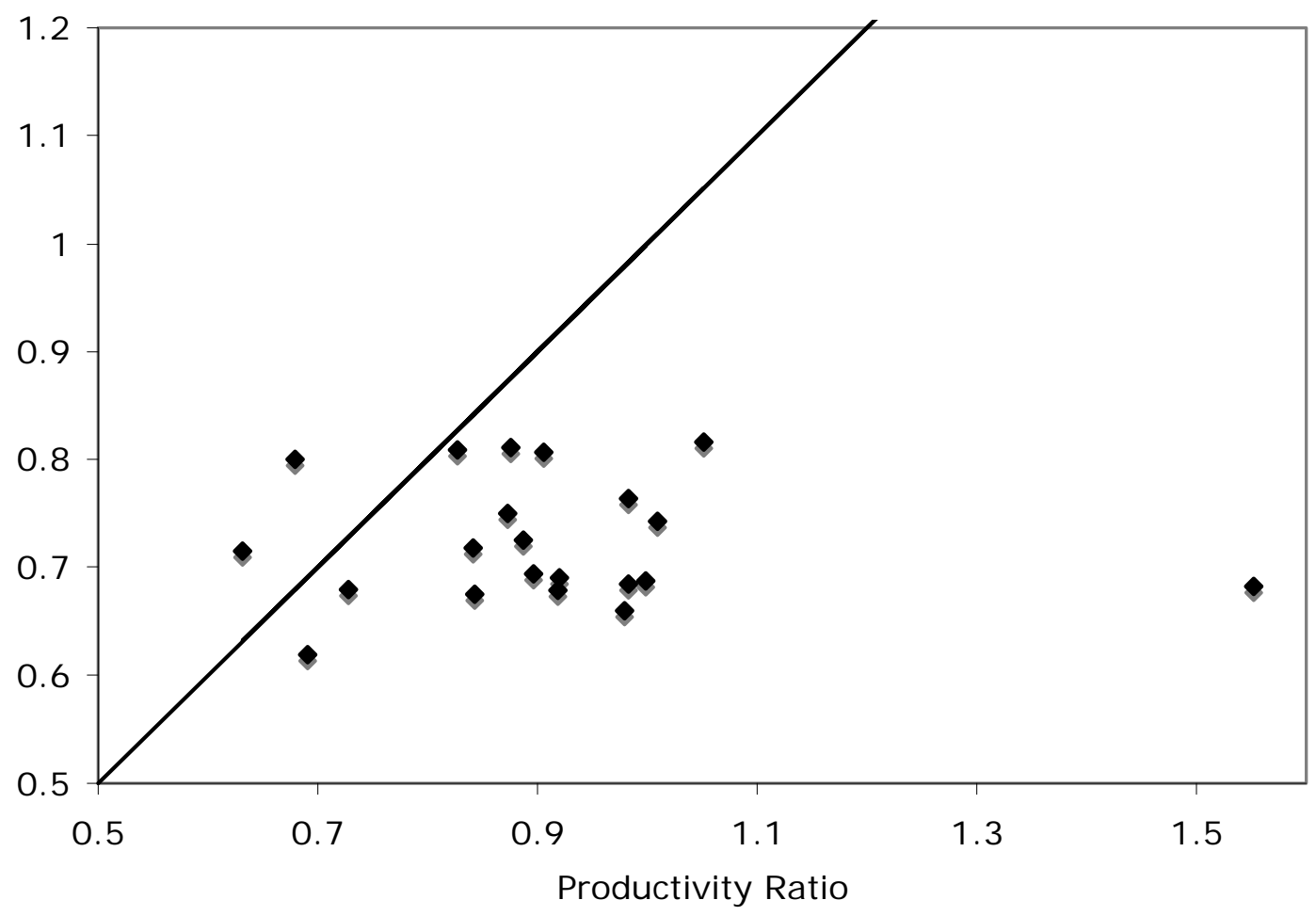

